\title{
Determination of the Health Services Vocational School Students' Thoughts and Usage Habits about Herbal Treatment
}

\author{
Gulsum YETIS $^{* 1}$, Turgay KOLAC ${ }^{1}$, Perihan GURBUZ ${ }^{1}$, Z. Deniz YAKINCI ${ }^{1}$ \\ ${ }^{1}$ Vocational School of Health, Inonu University, Malatya, Turkey
}

Received: 05 May 2017 - Revised: 10 September 2017 - Accepted: 01 October 2017

\begin{abstract}
Usage of complementary-alternative medicine (CAM) is increasing in a rapid manner. Among CAM, herbal applications come in the foreground. This cross-sectional study was conducted by using 'questionnaire application method' on 342 students in Inonu University Health Services Vocational School. Analyzes of the data was made by SPSS 17.0 programme by using frequency, percentage and q-square tests. According to the data, $44.1 \%$ of the students were obtained to use herbal treatment. Among students; $70,0 \%$ stated that they believed in alternative treatment, $72,5 \%$ said that the product they used had been good for themselves. The choiced herbal treatment products by students were; products that strengthen the body and the immune system, skin care products, hair care products, pain relief products, products for burn treatment, essences for perfume, slimming products in order. The rates of herbal treatment usage were found to be higher and statistically significant in the groups which; found herbal treatment usage correct, saw the benefits of the treatment that had already been used and were informed about the herbal treatment. It was determined that the students did not investigate different effects or usage purposes of the products they used. The unconscious use of herbal products can cause variety of health problems. Due to their youngness and vocations it is important to determine 'health services vocational high school students' knowledge level about herbal and alternative treatment. The purpose of this study was to determine the consciousness about herbal treatment and the usage of herbal remedies by health services vocational high school students.
\end{abstract}

Keywords: herbal treatment, plant, student

\section{INTRODUCTION}

Complementary-alternative medicine (CAM) is defined as 'group of diverse medical and healthcare systems, practices and products that are not presently considered to be part of conventional medicine [1]. CAM methods contain special medicine methods that use; natural substances and special solutions, different treatment and exercise techniques to protect the body and soul health [2]. CAM treatments can be grouped in three categories as natural products (herbal treatments, nutritional supplements), body and mind practices (acupuncture, massage, reflexology, etc.) and other complementary health approaches (ayurveda, homeopathy, etc.) [3]. Herbal practices constitute majority of these applications [4, 5]. Mankind has been using herbs since the first human. According to the archaeological findings, people have have benefited from plants to obtain nutrients and to solve health problems [6]. Throughout the history of

\footnotetext{
${ }^{*}$ Corresponding Author E-mail: gulsum.yetis@inonu.edu.tr
} 
humanity, many diseases (diabetes, hepatitis, shortness of breath, etc.) have been tried and are being tried to be treated by plants [6]. The concern on CAM methods has increased with the increase of; chronic diseases, cost of new technologies, the difficulties in reaching treatment facilities, suspicion and fear about the possible side effects of care and treatment methods and lack of sufficient time of healthcare team members [7-9]. CAM methods and especially herbal therapies are preferred highly in developing or underdeveloped countries, where traditional medical services are diffucult or expensive to reach $[4,10]$. World Health Organization (WHO) reports that, about 4 billion people around the world are trying to solve their health problems with herbal products as the first step. Moreover, about $25 \%$ of prescribed drugs in developed countries constitute plant-based active substances (vimblastine, reserpine, quinine, aspirin, etc.) [6]. While usage of CAM methods in developed countries have been determined to be as; $42.1 \%$ in America, 48.2\% in Australia, 49.3\% in France and 70.4\% in Canada, the rates in the developing countries have been determined as $71 \%$ in Chile, $70 \%$ in China, $40 \%$ in Colombia and $80 \%$ in Africa [11]. Another study in USA has reported the rate of CAM usage as $75 \%$ in adults [12].

As in the rest of the world, there is also a tendency to use herbal treatment in our country [13]. Herbal treatment has been determined to be the mostly preferred CAM method in researches [14]. Similarly, in a review study about CAM treatment in Turkey, it has been obtained that $66 \%$ of the individuals used herbal teas as complementary therapy, $18.9 \%$ used relaxation method [15] and $23.3 \%$ of elderly used massage therapy [16]. While it is a positive [13] approach to see complementary methods' usage by different groups in society [13], their unconscious use cause some health problems due to incorrect self diagnosis, inappropriate choice of herbal remedy [4, 17]. As an example, in a recent study some herbal teas have been shown to have antagonistic effects if used with some antibiotics [18]. Also herbal therapies are advised to be ceased at least two weeks before surgery becouse of their potential effects [19]. In fact when compared to medicines, the herbal products used may lead serious health problems and even death. The reason of this fact is; the active ingredients and the action mechanisms of most of the plants have not been explained through toxicological tests and/or controlled clinical trials and they are used often through advertisements on communication media and by people's own initiatives [20].By the fact that unconscious and high dose usage of plants may affect health in a negative manner, arrangements should be done in this topic [21]. Many countries have developed strict controlling systems for CAM methods [17]. The usage of CAM in our country has not been institutionalized and systematized yet [17]. There is no consensus in the science community about the effectiveness and safety of the methods [20].

Researches in different places of world have concluded that students commonly use and have favorable attitudes toward herbal remedies [4]. In the studies conducted with university students it has been determined that the most known [22, 23] and used [13] CAM method is herbal treatment among them. In a study made with medicine faculty students, it has been obtained that they find themselves knowledgeable about herbal therapy [2] and they want to have education about herbal treatment [23]. In other studies it was seen that the participants were informed about the herbal products mostly through media (television and internet) [17, 24]. Studies performed on herbal products have shown them to be preferred because of being believed to have no side effects as they are natural products. Although health care workers are important in preventing unconscious usage, researches have shown that health care providers have inadequate information about CAM [25]. By this point of view assessing the approach and knowledge level of students who are trained to work in the health field is important. The purpose of this study was to determine students' opinions about the usage of plants and herbal remedies in vocational health services school. 


\section{MATERIAL and METHODS}

This descriptive type of study was done with students studying in Inonu University Health Services Vocational School in 2016-2017 academic year. It was aimed to reach the whole of the universe without using sample selection method in the research. However, those who refused to participate in the survey and those who did not attend the school at the time of the survey were excluded from the survey. 342 students formed the sample of the research. A questionnaire prepared by researchers, consisting of questions about; the socio-demographic characteristics of students, thoughts about herbal treatment and usage of herbal medicines was used in the collection of data.

Questionnaires were completed by the students in 10-15 minutes and the completed forms were collected by the researchers. Analyzes of the obtained data were done by frequency, percentage and chi-square analysis using SPSS 17.0 program. The results were evaluated in a confidence interval of $95 \%$ and a significance level of $p<0.05$. For the realization of the research, written approval from Inonu University Health Care Vocational School and Inonu University Ethics Committee. Oral improvement from the students were obtained before questionnaire usage. The fact that the research includes only the views of the students from a university campus and therefore the views of the other sections of the society can not be reflected can be considered as the limitation of this research.

\section{RESULTS}

Of the 342 students who participated in the survey; $69.3 \%$ were girls, $73.5 \%$ had moderate economic status. Their average age was $20.33 \pm 3.49$. 7.6\% of the students had a chronic illness requiring medication (Table 1 ).

Table 1. Sociodemographic Characteristics of Students

\begin{tabular}{lll}
\hline Demographic Findings & Number & $\%$ \\
Sexuality & & 69,3 \\
Girl & 237 & 30,7 \\
Male & 105 & 20,3 \\
Economical situation & & 73,5 \\
Good & 69 & 6,2 \\
Moderate & 250 & 7,6 \\
Bad & 21 & 92,4 \\
Chronic disease requiring drug use & 26 & \\
Yes & 314 & \\
No & & \\
\hline
\end{tabular}

$70.2 \%$ of the students stated that they had heard alternative treatment and $70.0 \%$ believed in alternative treatment. 52.4\% said that there existed people in the surrounding using alternative therapy, $14.8 \%$ stated that they did not find alternative treatment correct, $45.1 \%$ had no idea about the effectiveness of alternative treatment (Table 2). Reasons for not finding the treatment correct were; "Unconscious use of patients" $(29,2 \%)$ and "Absense of training on herbal treatment" $(28,6 \%)$. While $21.3 \%$ of the students found the plants safer on the reliability of medicines and plants, $52.2 \%$ of the students stated that they found both drugs and plants safe. $64.5 \%$ stated that they had never been informed about herbal or alternative treatment and $46.9 \%$ stated that they did not have any idea about herbal treatment. Of the informed students; $44.4 \%$ of them were found to have been informed from the internet while $40.5 \%$ were informed from TV programs or advertisements, and $32.4 \%$ were informed from previous users (Table 2). $44.1 \%$ of the students stated that they had used alternative treatment. $70.6 \%$ of the students who used herbal products stated that they used the products when they needed, $32.5 \%$ of the students 
said that they had benefited from their complaints after the use of herbal remedies, and $61.6 \%$ recommended the products they used.

Table 2. Knowledge and Opinions of Students about Alternative Treatment

\begin{tabular}{lll}
\hline Have you heard of alternative treatment methods? & Number & $\%$ \\
Yes & 233 & 70,2 \\
No & 99 & 29,8 \\
Do you believe in alternative treatment? & 229 & 70,0 \\
Yes & 98 & 30,0 \\
No & & \\
Do you use herbal remedies in your area? & 176 & 52,7 \\
Yes & 158 & 47,3 \\
No & & \\
Do you find the alternative treatment correct? & 135 & 40,1 \\
Yes & 50 & 14,8 \\
No & 152 & 45,1 \\
No idea & & \\
Do you have any cure for herbal remedies? & 76 & 22,7 \\
Yes & 102 & 30,4 \\
No & 157 & 46,9 \\
No idea & & \\
Which one is more trustworthy, drug or plant? & 169 & 52,2 \\
Both are safe & 69 & 21,3 \\
Plant use is safe, drugs are not & 44 & 13,6 \\
Drug use is safe, plants are not & 42 & 13,0 \\
Neither drug nor plant is safe & & \\
Have you been informed about herbal treatment? & 118 & 35,5 \\
Yes & 214 & 64,5 \\
No & & 44,4 \\
Where did you get information? & 148 & 40,5 \\
Internet & 135 & 32,4 \\
TV / advertising & 108 \\
Internet Users & 103 & 30,9 \\
Health book & 67 & 20,1 \\
Healthcare & 49 & 14,7 \\
\hline Newspaper / magazine & & \\
& & \\
\hline
\end{tabular}

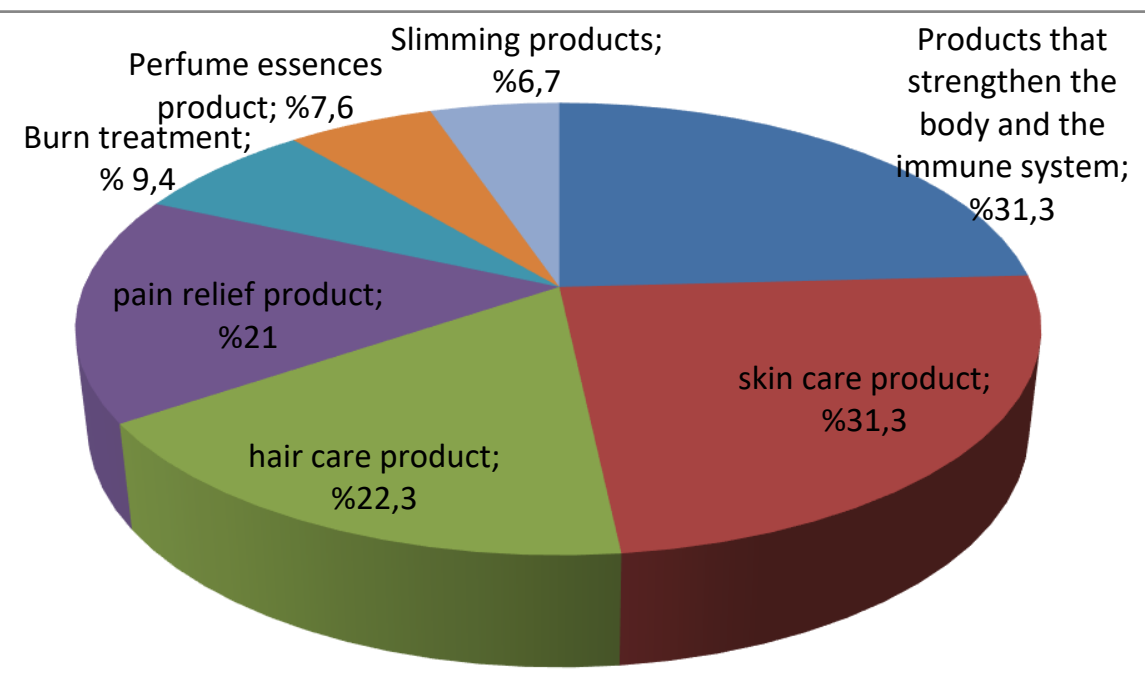

Figure 1. Usage Rates of Herbal Remedies 
Participants' usage rate of herbal remedies has been found as; and skin care products (31.3\%), hair care products $(22.3 \%)$, pain relief products $(21.0 \%)$ and products for burn treatment, perfume essences (7.6\%) and slimming products (6.7\%) in order. (Graphic1)

$30.8 \%$ of the respondents stated that they did not investigate whether the product used had another effect or not, while $72.4 \%$ stated that they did not consult the doctor for herbal treatment. The reasons for not consulting a doctor was; not to need $81.5 \%$, possibility of negatory reaction $5.2 \%$ and fear of being criticized 3,0\% (Table 3). It is stated that $40.9 \%$ of the students purchase the products from the herbalists, $72.5 \%$ said that the product they used was good for themselves, and $13 \%$ said that the product they used had been harmful to them.

Table 3: Alternative Treatment Usage Situations of Students

\begin{tabular}{lll}
\hline & Number & $\%$ \\
Do you use alternative treatment? & 150 & 44,1 \\
Yes & 190 & 55,9 \\
No & & \\
Where do you get the products you use? & 97 & 40,9 \\
I take from the herbalist & 61 & 25,7 \\
I take from pharmacy & 23 & 9,7 \\
I collect myself & 22 & 9,3 \\
I buy from market & 21 & 8,9 \\
I take from friends / relatives & 5 & 2,1 \\
I order from TV or internet & & \\
Was the product used good for you? & 140 & 72,5 \\
Yes & 22 & 11,4 \\
No & 31 & 16,1 \\
No idea & & 13,0 \\
Was the product used harmful for you? & 25 & 87,0 \\
Yes & 168 \\
No & & 14,8 \\
What are you waiting from herbal products? & 35 & 29,5 \\
Strengthen my immunity & 70 & 32,5 \\
Reduce complaints & 77 & 14,3 \\
Benefit / Discharge of complaints & 34 & \\
Prevent repetition of my complaint & & 27,6 \\
Have you consulted a doctor for the use of herbal products? & 53 & 72,4 \\
Yes & 139 & 5,2 \\
No & & 81,5 \\
What is your reason for not consulting a doctor? & 7 & 3,0 \\
I thought he would react negatively & 110 \\
I did not need & 4 & 10,4 \\
I'm afraid of criticism & 14 & \\
Other & & \\
\hline & &
\end{tabular}

The difference between the economical status of students and the use of herbal treatment was statistically significant $(\mathrm{p}<0,05)$. While the rate of herbal treatment usage in the economically poor evaluated group was $66,7 \%$, the rates were $45,6 \%$ in moderate and $31.9 \%$ in good economic groups (Table 4). 
Table 4. Comparison of Students' Economic Situations and Herbal Treatment Usage Situations

\begin{tabular}{llllll}
\hline $\begin{array}{l}\text { Herbal treatment } \\
\text { Economical }\end{array}$ & $\begin{array}{l}\text { Users } \\
\text { Number }\end{array}$ & $\%$ & $\begin{array}{l}\text { Non users } \\
\text { Number }\end{array}$ & $\%$ & Significance \\
$\begin{array}{l}\text { situation } \\
\text { Good }\end{array}$ & 22 & 31,9 & 47 & 68,1 & $\mathrm{x}^{2}=8,731$ \\
Moderate & 113 & 45,6 & 135 & 54,4 & $\mathrm{p}=0.013$ \\
Bad & 14 & 66,7 & 7 & 33,3 & \\
\hline
\end{tabular}

Table 5. Comparison of Herbal Treatment Usage Situations and Herbal Treatment Considerations of Students

\begin{tabular}{|c|c|c|c|c|c|}
\hline \multirow{2}{*}{ Herbal treatment } & \multicolumn{2}{|l|}{ Users } & \multicolumn{2}{|c|}{ Non users } & \multirow{2}{*}{ Significance } \\
\hline & Number & $\%$ & $\mathrm{~S}$ & $\%$ & \\
\hline \multicolumn{6}{|c|}{ Do you find herbal treatment correct } \\
\hline Yes & 80 & 59,3 & 55 & 40,7 & \multirow{3}{*}{$\begin{array}{l}\mathrm{x}^{2}=22,10 \\
\mathrm{p}=0.000\end{array}$} \\
\hline No & 14 & 28,0 & 36 & 72,0 & \\
\hline No idea & 54 & 35,8 & 97 & 64,2 & \\
\hline \multicolumn{6}{|c|}{ Was the treatment you used good for your health? } \\
\hline Yes & 120 & 85,7 & 20 & 14,3 & \multirow{3}{*}{$\begin{array}{l}x^{2}=26,54 \\
p=0.000\end{array}$} \\
\hline No & 11 & 50,0 & 11 & 50,0 & \\
\hline No idea & 15 & 50,0 & 15 & 50,0 & \\
\hline \multicolumn{6}{|c|}{ Have you been informed about herbal treatment? } \\
\hline Yes & 71 & 60,2 & 47 & 39,8 & $x^{2}=23,15$ \\
\hline No & 70 & 32,9 & 143 & 67,1 & $\mathrm{p}=0.000$ \\
\hline
\end{tabular}

There was statistically significant difference between the groups which; used herbal treatment, believed in correctness of herbal treatment, had benefited from the treatment used, and had been informed about herbal treatment $(\mathrm{p}<0,05)$. The usage rate of herbal treatment was higher in groups which; found herbal treatment correct $(59.2 \%)$, saw the benefit of previous treatment $(85.7 \%)$ and had been informed about herbal treatment $(60.2 \%)$, than the other groups (Table 5).

Table 6. Comparison of Student Gender and Alternative / Herbal Treatment Considerations

\begin{tabular}{llllll}
\hline Sexuality & $\begin{array}{l}\text { Girl } \\
\text { Number }\end{array}$ & $\%$ & $\begin{array}{l}\text { Boy } \\
\text { S }\end{array}$ & $\%$ & Significance \\
$\begin{array}{l}\text { Alternative treatment } \\
\text { Believe }\end{array}$ & 153 & 66,8 & 76 & 33,2 & $\mathrm{x}^{2}=1,41$ \\
Not believe & 72 & 73,5 & 26 & 26,5 & $\mathrm{p}=0.234$ \\
Alternative / herbal treatment & & & & & \\
Find it right & 85 & 63,0 & 50 & 37,0 & $\mathrm{x}^{2}=4,44$ \\
Does not find it right & 37 & 74,0 & 13 & 26,0 & $\mathrm{p}=0.108$ \\
No idea & 112 & 73,7 & 40 & 26,3 & \\
Alternative / herbal treatment & & & & & \\
Used & 105 & 70,0 & 45 & 30,0 & $\mathrm{x}^{2}=0,09$ \\
Didn't use & 130 & 68,4 & 60 & 31,6 & $\mathrm{p}=0.754$ \\
Alternative / herbal treatment & & & & & \\
Harmful & 55 & 72,4 & 21 & 27,6 & $\mathrm{x}^{2}=3,86$ \\
Not harmful & 63 & 61,8 & 39 & 38,2 & $\mathrm{p}=0,14$ \\
No idea & 114 & 72,6 & 43 & 27,4 & \\
\hline
\end{tabular}


The difference between the gender of the students and; usage of herbal treatment, belief in herbal treatment, opinion about herbal treatment to be necessary or harmful were statistically insignificant ( $\mathrm{p}>0,05)$ (Table 6).

When the students' gender was compared with the aim of the usage of herbal products, there was statistically significance in skin care, painkiller and perfume products usage $(p<0,05)$. According to herbal treatment usage purposes; $88.6 \%$ of those who used for skin care and $59.6 \%$ for pain relief were female students while $58.8 \%$ of those using as perfume were male students (Table 7).

Table 7: Comparison of the Gender of Students with the Purposes of Herbal Products Usage

\begin{tabular}{llllll}
\hline Sexuality & $\begin{array}{l}\text { Girl } \\
\text { Number }\end{array}$ & $\%$ & $\begin{array}{l}\text { Boy } \\
\text { Number }\end{array}$ & $\%$ & significant \\
$\begin{array}{l}\text { For pain relief } \\
\text { Using }\end{array}$ & 28 & 59,6 & 19 & 40,4 & $\mathrm{x}^{2}=5,22$ \\
$\begin{array}{l}\text { Not using } \\
\text { For skin treatment }\end{array}$ & 135 & 76,3 & 42 & 23,7 & $\mathrm{p}=0.022$ \\
using & 62 & 88,6 & 8 & 11,4 & $\mathrm{x}^{2}=12,83$ \\
Not using & 101 & 65,6 & 53 & 34,4 & $\mathrm{p}=0.000$ \\
For parfum purpose & & & & & \\
Using & 7 & 41,2 & 10 & 58,8 & $\mathrm{x}^{2}=9,26$ \\
Not using & 156 & 75,4 & 51 & 24,6 & $\mathrm{p}=0.002$ \\
\hline
\end{tabular}

\section{DISCUSSION}

There are few studies in the literature about alternative and/or herbal product usage conducted with healthy individuals and university students. Of the 342 students who participated in the study $7.6 \%$ had a chronic disease requiring medication. The result of the study conducted by Sucakl1 and his colleagues (2014), in which 7.7\% of the young people had a chronic illness, shows similarity with our study [24].

$44.1 \%$ of the students stated that they used alternative treatment. This result is similar with Awad's research in which CAM usage rate was found to be $55.2 \%$ in university students [1]. In another research made by Columbia university CAM usage in the last 12 years has been found as $82 \%$, this result is higher than our result but this fact can be explained by the CAM perception in the researches [26]. The first three usage statements of the herbal treatment applications are; products which strengthen the body and immune system (31,3\%), skin care products $(31,3 \%)$ and hair care products $(22,3 \%)$ (Graphic 1). In the study conducted by Sucakl1 and his colleagues, $38.5 \%$ of the university students applied herbal products and traditional methods primarily for; illness $(58.4 \%)$, protection against diseases $(46.6 \%)$ and skin problems (29.3\%) [24]. Herbal treatments are mostly used for losing weight [27]. However, weight loss products $(6.7 \%)$ take the last place in our study. This is thought to be due to the fact that the body mass indexes (BMI) of our sample group are within the normal range. In our research, $72.5 \%$ of students stated that the product had been good for themselves, and $13 \%$ of students stated that the product used had been harmful to themselves (Table 3). The rate of students who benefited from the herbal treatment in Sucaklı and his colleagues'(2014) study $(67.6 \%)$ has a close proximity and similar results with our research.

Recent studies show that; herbal products are preferred as they are believed to have no side effects as natural products. Although people are familiar with CAM and herbal supplements they have little experience and knowledge about them [28]. People decide to use the products regarding the media and the market [20] and also the people are affected by the mass media about CAM applications [11]. In this research; 52.2\% of the students stated that they found both plants and plants safe, while $21.3 \%$ stated that herbs were more reliable than 
drugs (Table 2). In a recent study conducted with people over 18 years -making shopping from a herbalist-, show that the most important convincing factor for the participants about the reliability of herbal products were; the approval of the Ministry of Health or the Ministry of Agriculture and Rural Affairs (59.5\%) and the experience of other patients that suffered from the same diseases $(18.9 \%)$ [27].

In this study $44,4 \%$ of the students were found to have information about herbal treatment from internet while 40,5\% had information from TV programmes or advertisements (Table 2). Regarding the results of having the information through TV programmes and internet our study has similar results with Gamsızkan's research with doctors and Sucaklı and colleagues' research with university students [17, 24]. But this result is different from Sawalha and Oliveira's results in which students were determined to use hermal remedies according to their own knowledge and advices of family and/or friends [4, 29].

In this study $72.4 \%$ of the students stated that they did not consult the doctor for the usage of herbal treatment, $81.5 \%$ of them stated that they did not need to consult and $5.2 \%$ stated that they thought the doctor would react in a negative manner (Table 3). In a study conducted, it was determined that $74.2 \%$ of individuals over the age of 18 did not consult the doctor about using herbal remedies because of the thought that the doctor would not confirm (32.6\%) and it was shown that doctors were not recommending usage of CAM methods [11]. Another study has reported that, $70 \%$ of patients using herbal products, healthcare support products or products sold outside of pharmacies do not report usage to the physician or other health personel as they do not think herbal products to have physiological effects and therefore do not think them to be as medicine [16].

In our research the difference between the gender of the students and the use of herbal treatment; for skin care, as painkiller or perfume was found to be statistically significant ( $\mathrm{p}$ $<0,05$ ). While the majority of those using herbal treatment for skin care and pain relief were girls, those who used as perfume were mostly male. However, the difference between the gender of the students and the use of herbal treatment, belief in herbal remedies or believe it to be harmful were statistically insignificant ( $p>0.05$ ). The results of Sucakli (2014) [24] and Ozcelik (2015) [11] also suggest that the difference between male and female gender in using herbal products is meaningless and supports our research. The results of Featherstone, Awad and Sawalha's studies in which women were found to use herbal remedies more than males [1, $2,4]$, differ from our research.

\section{CONCLUSION}

While $44.1 \%$ of the students stated that they used herbal treatment, it was determined that $30.8 \%$ did not investigate whether the product used had another effect or not. The unconscious use of herbal products can cause a variety of health problems. Considering that the information about the alternative and herbal treatment is mostly obtained from the internet and TV programs, it turns out that the mass media is playing an active role in directing the public. The effects of non-pharmaceutical methods used in various diseases on existing medical treatments should be investigated and patients should be made aware of the use of herbal products. Health care workers are in an important position to prevent unconscious use. It is important to determine the information level of vocational school students in health services about herbal and alternative treatment due to their youngness and vocation. In this regard, it is advisable to perform new studies with different sample groups.

\section{Acknowledgement}

The authors are grateful to all students for acceptance of the research. 


\section{REFERENCES}

[1] Awad, A. I., Al-Ajmi, S., \& Waheedi, M. A. (2012). Knowledge, perceptions and attitudes toward complementary and alternative therapies among Kuwaiti medical and pharmacy students. Medical principles and Practice, 21(4), 350-354.

[2] Ergin, A., Hatipoğlu, C., Bozkurt, A. İ., Mirza, E., Kunak, D., Karan, C., \& Pırtı, İ. (2011). Uzmanlık ve tıp öğrencilerinin tamamlayıc1-alternatif tıp hakkındaki bilgi düzeyleri ve tutumlar1. Pamukkale Tip Dergisi, 4(3), 136-143.

[3] Kaplan Algin A., Turk A. (2016) Tamamlayici Terapi Uygulamalari: Turkiye'deki Akupunktur, Kayropraksi Uygulamalari, 1st International and 3rd National Congress on Complementary Therapies and Supportive Care Practices, 24-26 sept, p.74. Antalya, Turkey.

[4] Sawalha, A. F., Sweileh, W. M., Sa'ed, H. Z., \& Jabi, S. W. (2008). Self-therapy practices among university students in Palestine: focus on herbal remedies. Complementary therapies in medicine, 16(6), 343-349.

[5] NCCIH (2016), Complementary Alternative or Integrative Health: What's In a Name?, 28 June, https://nccih.nih.gov/health/integrative-health\#types.

[6] Faydaoğlu, E., \& Sürücüoğlu, M. S. (2011). Geçmişten günümüze tıbbi ve aromatik bitkilerin kullanılması ve ekonomik önemi. Kastamonu Üniversitesi Orman Fakültesi Dergisi, 11(1), 52-67.

[7] Khorshid, L., \& Yapucu, Ü. (2005). Tamamlayıcı Tedavilerde Hemşirenin Rolü. Journal of Anatolia Nursing and Health Sciences, 8(2).

[8] Molassiotis, A., Fernadez-Ortega, P., Pud, D., Ozden, G., Scott, J. A., Panteli, V., \& Madsen, E. (2005). Use of complementary and alternative medicine in cancer patients: a European survey. Annals of oncology, 16(4), 655-663.

[9] Turan, N., Öztürk, A., \& Kaya, N. (2010). Hemşirelikte yeni bir sorumluluk alanı: Tamamlayıc terapi. Maltepe Üniversitesi Hemşirelik Bilim ve Sanatı Dergisi, 3(1), 93-8.

[10] Suleman, S., Ketsela, A., \& Mekonnen, Z. (2009). Assessment of self-medication practices in Assendabo town, Jimma zone, southwestern Ethiopia. Research in social and administrative pharmacy, 5(1), 76-81.

[11] Özçelik, H., \& Fadıloğlu, Ç. (2009). Kanser hastalarının tamamlayıcı ve alternatif tedavi kullanım nedenleri. Türk Onkoloji Dergisi, 24(1), 48-52.

[12] Barnes, P. M., Powell-Griner, E., McFann, K., \& Nahin, R. L. (2004, June). Complementary and alternative medicine use among adults: United States, 2002. In Seminars in integrative medicine (Vol. 2, No. 2, pp. 54-71). WB Saunders.

[13] Sari G., Kipay S. S. (2008) Meslek Yuksekokulu Ogrencilerinin Alternatif/Tamamlayici Tedavi Yontemlerini Kullanma Durumlarinin Belirlenmesi, VI. Ulusal Hemsirelik Egitimi Uluslararasi Katilimli Kongresi, İstanbul, Turkey.

[14] Ventola C. L. (2010) Current Issues Regarding Complementary and Alternative Medicine (CAM) in the United States, Policies and Practices Regarding Dietary Supplements In Health Care Facilities, 35(10): 570-576.

[15] Kav, S., Hanoğlu, Z., \& Algier, L. (2008). Türkiyede Kanserli Hastalarda Tamamlayıcı ve Alternatif Tedavi Yöntemlerinin Kullanımı: Literatür Taraması. International Journal of Hematology \& Oncology/UHOD: Uluslararasi Hematoloji Onkoloji Dergisi, 18(1).

[16] Dedeli, Ö., \& Karadakovan, A. (2011). Yaşlı bireylerde ilaç kullanımı, tamamlayıcı ve alternatif tedavi uygulamalarının incelenmesi. Spatula DD, 1(1), 23-32.. 
[17] Gamsizkan, Z., Kurt, E., Yücel, A., \& Kartal, M. (2011). Hekimlerin fitoterapi ürünlerine bakış açısı. J Clin Anal Med, 2, 1-3.

[18] Hacioglu, M., Dosler, S., Tan, A. S. B., \& Otuk, G. (2017). Antimicrobial activities of widely consumed herbal teas, alone or in combination with antibiotics: an in vitro study. PeerJ, 5, e3467.

[19] Hodges, P. J., \& Kam, P. C. A. (2002). The peri-operative implications of herbal medicines. Anaesthesia, 57(9), 889-899.

[20] Traş, B., Üney, K., \& Traş, S. (2012). Bitkisel ürünlerle ilgili sağlık sorunları. Bilim ve Teknik Dergisi, 534, 48-53.

[21] Şarışen, Ö., \& Çalışkan, D. (2005). Fitoterapi: Bitkilerle Tedaviye Dikkat (!). Sted, 14(8), 182-187.

[22] Nilgün, Ç. Ö. L., Taşdemir, H. S., \& Kılıç, S. P. (2012). Sağlık Bilimleri Fakültesi Öğrencilerinin Tıp Dışı Alternatif Ve Geleneksel Uygulamalar Konusundaki Görüşlerinin Değerlendirilmesi. Gümüşhane Üniversitesi Sağllk Bilimleri Dergisi, 1(4), 239-251.

[23] Altan, S., Rahman, S., \& Çam, S. (2014). Tıp Fakültesi Öğrencilerinin Tamamlayıcı ve Alternatif Tıp Yöntemleri ile İlgili Bilgi ve Tutumları. Turkiye Klinikleri Journal of Medical Ethics-Law and History, 22(3), 81-88.

[24] Sucakl1, M. H., Ölmez, S., Keten, H. S., Yenicesu, C., Sarı, N., \& Çelik, M. (2014). Üniversite öğrencilerinin bitkisel ürünleri kullanım özelliklerinin değerlendirilmesi. Medicine Science, 3(3), 1352-60.

[25] Bjerså, K., Victorin, E. S., \& Olsén, M. F. (2012). Knowledge about complementary, alternative and integrative medicine (CAM) among registered health care providers in Swedish surgical care: a national survey among university hospitals. BMC complementary and alternative medicine, 12(1), 42.

[26] Versnik Nowak, A. L., DeGise, J., Daugherty, A., O'Keefe, R., Seward Jr, S., Setty, S., \& Tang, F. (2015). Prevalence and predictors of complementary and alternative medicine (CAM) use among Ivy League college students: Implications for student health services. Journal of American College Health, 63(6), 362-372.

[27] Özçelik, G., \& Toprak, D. (2014). Bitkisel Tedavi Neden Tercih Ediliyor?, Ankara Med J, 15(2): 48-58.

[28] Zimmerman, C. (2012). A pilot study to assess students' perceptions, familiarity, and knowledge in the use of complementary and alternative herbal supplements in health promotion. Alternative therapies in health and medicine, 18(5), 28.

[29] Oliveira, S. G. D., de Moura, F. R. R., Demarco, F. F., da Silva Nascente, P., Del Pino, F. A. B., \& Lund, R. G. (2012). An ethnomedicinal survey on phytotherapy with professionals and patients from Basic Care Units in the Brazilian Unified Health System. Journal of Ethnopharmacology, 140(2), 428-437. 